\title{
CAVE TURBIDITES
}

\section{JAMSKI TURBIDITI}

\author{
R. Armstrong L. OSBORNE ${ }^{1}$
}

\begin{abstract}
R. Armstrong L. Osborne: Cave turbidites

Turbidites are uncommon in caves, but are more common as palaeokarst deposits. Marine carbonate turbidites, called caymanites, are the most common cave and palaeokarst turbidites, but marine non-carbonate turbidites, freshwater carbonate turbidites and freshwater non-carbonate turbidites are also deposited in caves and preserved in palaeokarst sequences. One of the most complex sequences of cave turbidites occurs in the Wellington Caves Phosphate Mine in Australia. Cave turbidites form in ponded water in caves and may be triggered by floods and high intensity rain events. While caymanites are most likely to form during marine transgressions, they can be emplaced by tsunami. Freshwater cave turbidites are most likely to form in flooded hypogene caves located in the seasonally wet tropics and in areas with irregular high intensity rainfall events.
\end{abstract}

Key words: cave sediments, turbidites, palaeokarst, caymanites.

\section{Izvleček}

UDK 551.3.051:551.44

\section{R. Armstrong L. Osborne: Jamski turbiditi}

Sedimenti odloženi iz turbiditnih tokov so v recentnih jamah relativno redki, bolj pogosto pa se pojavljajo kot paleokraški sedimenti. Tako med jamskimi kot paleokraškimi turbiditi so najpogostejši kajmaniti, ki so nastali s presedimentacijo izvorno morskega karbonatnega sedimenta. Tako v recentih jamah kot v paleokraških sekvencah najdemo tudi nekarbonatne morske in karbonatne ter nekarbonatne sladkovodne turbidite. Ena najbolj kompleksnih sekvenc jamskih turbiditiov se nahaja v sklopu fosfatnega rudnika »Wellinton Caves« v Avstraliji. Sedimentacijo jamskih turbiditov, ki se odlagajo v sigastih ponvicah, lahko sprožijo poplavni dogodki ali močna deževja. Kajmaniti se zelo verjetno odlagajo med transgresijo morja, sprožijo pa jih lahko tsunamiji. Sladkovodni jamski turbiditi se najpogosteje odlagajo v poplavljenih hipogenih jamah tropskih območij s sezonskih vlažnim obdobjem in v območjih $\mathrm{z}$ občasnimi močnimi nalivi.

Kjučne besede: jamski sedimenti, turbiditi, paleokras, kajmaniti.

\section{INTRODUCTION}

Turbidites can be deposited in still bodies of water in caves. These range from large phreatic lakes to small rimpools developed on the side of stalagmites positioned high above the water table.

While fine graded-bedded sands and muds are the most common turbidites found in caves, large deposits resulting from the slumping of entrance facies and biogenic talus cones into phreatic lakes can result in deposition of both turbidite conglomerates (Walker, 1975) and all of the elements of the Bouma sequence (Bouma, 1962).

${ }^{1}$ Faculty of Education and Social Work, A35, University of Sydney, NSW 2006, Australia; a.osborne@edfac.usyd.edu.au Received/Prejeto: 06.12.2007 


\section{DISTRIBUTION}

There are few reports of cave turbidites in the literature. Most accounts describe palaeokarst deposits, with marine palaeokarst turbidites (caymanites), receiving the greatest attention (see Korpás, 2002). There are fewer reports of non-carbonate turbidites filling karst cavities; the most striking is that of Marschalko and Mello (1993) who described a $38 \mathrm{~m}$ thick sequence of graded sandstones and mudstones filling karst cavities exposed in Gombasek Quarry in eastern Slovakia.

By far the most abundant occurrences of cavity-filling turbidites are those found in surface exposures of palaeokarst deposits. Good examples of these are the laminated micrites of Otoničar (1997). Cavity-filling turbidite deposits are frequently quite small, but stand out from the enclosing bedrock because of their well-developed and often colourful laminations (Fig. 1A and 1D).

Most palaeokarst turbidites exposed in caves are caymanites, described further below. There are very few reported examples of non-marine palaeokarst turbidites exposed in caves. Some of the best examples are the exposures in the walls of Okno Cave in Slovakia, described by Osborne (2007; Fig. 1B). Freshwater palaeokarst carbonate turbidites occur in a quarry in southwestern Slovenia and an unroofed cave near Trieste, Italy.

The Wellington Caves Phosphate Mine in central western NSW, Australia, exposes a remarkable range of turbidite facies exposed in a former cave (Fig. 1C).

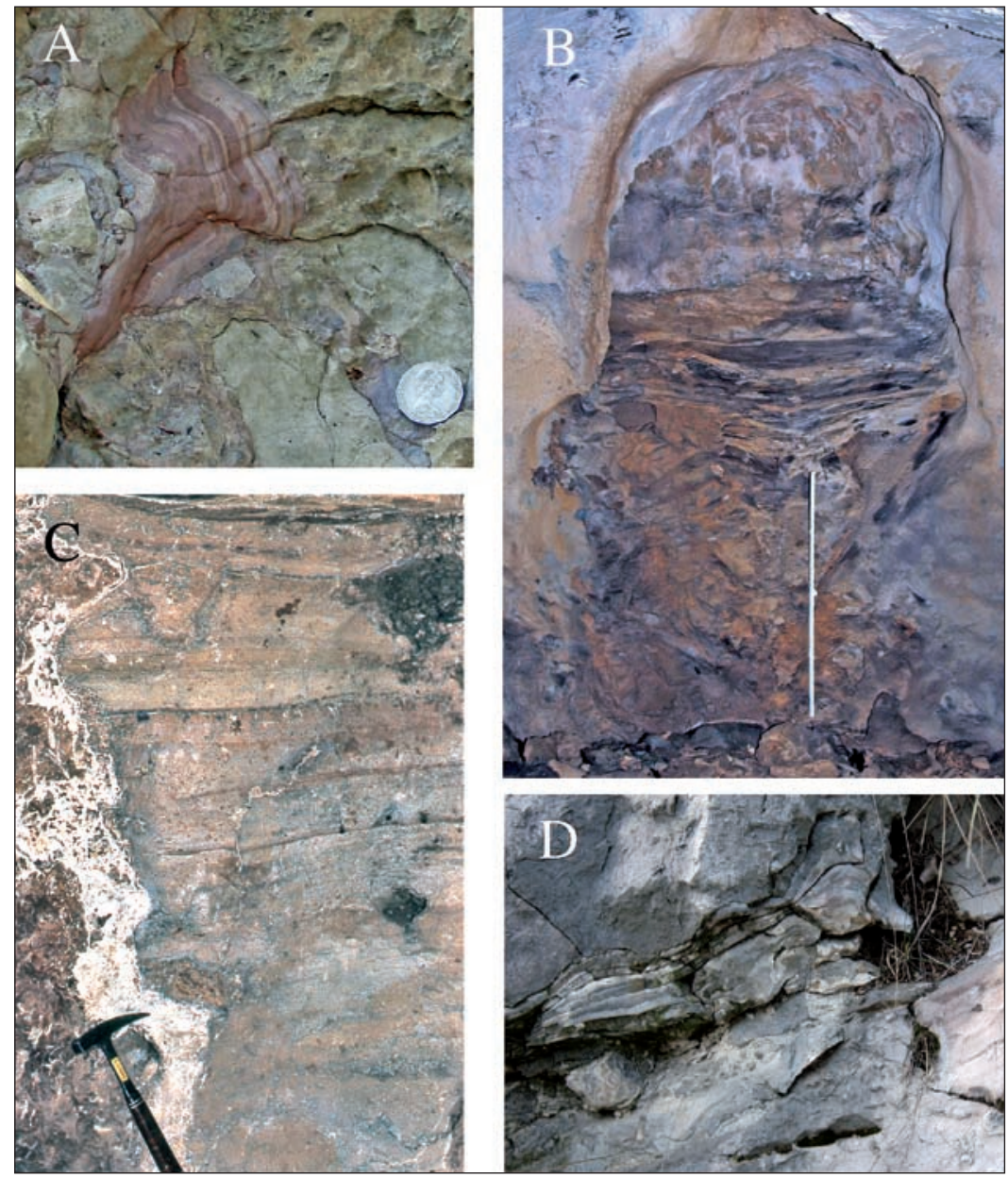

Fig. 1: Palaeokarst turbidite exposures. A - Laminated palaeokarst microturbidite with high initial dip at Douglas River, Northern Territory, Australia. Host rock is Cambrian Tindall Limestone. The age of palaeokarst is unknown. Coin diameter is $31 \mathrm{~mm} ; B-E x-$ posure of sequence of lithified palaeokarst sediments including turbidites, Okno Cave, Slovakia. Scale is $1 \mathrm{~m}$. Host rock is Triassic Gutenstein Limestone. Turbidite is probably Palaeocene in age; $C$-Sequence of graded-bedded sandstones exposed in the Wellington Caves Phosphate Mine, Wellington Caves, NSW, Australia. Distinct lines across strata are mud crack horizons. Host rock is Devonian limestone. Turbidite is Pliocene in age; D - Laminated microturbidite, in cutting on road between Basovizza and Padricano, Trieste Carso, Italy. Host rock is Late Cretaceous (Santonian) limestone. Turbidite is probably marine and Late Cretaceous (Mastricjtian) in age.

\section{ENVIRONMENTS AND MECHANISMS OF DEPOSITION}

While turbidites from deep marine environments are best known to geologists, turbidites were first described from Lake Mead, the water impounded by the Hoover Dam on the Colorado River in the USA by Grover \& Howard (1938). Walker (1969) pointed out that turbidites are in- dicative of a process of deposition in quiet water and not indicative of water depth.

The essential requirements for turbidite deposition are a still body of water and a rapid input of sediment or sudden disturbance of a sediment body within the wa- 
ter. Gravity and the density difference between the turbid and clean water does the rest. In the case of caves, the important components are a cave or small cavity, still water and a sediment source.

A number of processes have been responsible for ponding in caves where turbidites occur. Old hypogene caves, poorly connected to the modern hydrological system, can easily flood, as there is no simple path for water to flow out of the cave. The ponds in which the Wellington Caves Phosphate Mine turbidites formed probably resulted from sediment blockage of poor hydrological connections. Local ponding and sediment disturbance due to flooding has been implicated in turbidite deposition in McEachern's Deathtrap Cave, in South Australia by Kos (2001). Sediment disturbance due to flooding is also involved in the case of active cave turbidite deposition reported by Hosie \& Smith (2005). Turbidites in Olahola Cave, Norway formed in an ice-dammed lake (Valen et al., 1995).

While marine transgression and slumping of sediment cones inside caves appear to be the most common mechanisms for cave turbidite deposition, more exotic origins have been suggested. Burney et al. (2001) in their study of the Māhäulepū Caves and Sinkhole on Kaua'i, Hawaiian Islands, described a unit consisting of allochthonous stones and fractured bedrock, $1 \mathrm{~m}$ thick on the seaward facing wall of the cave and extending throughout the cave as turbidite fans and gravel beds. Burney et al. proposed that this unit resulted from a marine overwash probably due to a tsunami inundating the site.

\section{SOME SPECIAL FEATURES OF CAVE TURBIDITES}

\section{THE INFLUENCE OF CAVE GEOMETRY}

Turbidites mostly occur in marine and lacustrine environments where the depositional front is able to spread out, resulting in the unconstrained deposition of turbidite fans. This will occur in caves if the lake or pond is large relative to the size of the current, as in the case of Māhäulepū Caves and Sinkhole described by Burney et al. (2001).

When turbidites are deposited in narrow or network caves, we should expect the cave walls to channel the progress of the turbidity current. This interaction needs to be studied using physical models in flumes. In the absence of such studies, we might expect a large current in a narrow cave to behave like a current in a submarine canyon (see Fig. 10 of Walker 1975). The current would deposit conglomerate facies along the main channel, with fan lobes extending into side passages depositing gradedbedded sands and distal muds (Fig. 2).

\section{HIGH INITIAL DIP}

Many palaeokarst microturbidites have steeply-dipping laminae (Fig. 1A). This can lead to the false assumption that these sediments are deformed. It is more likely that these are showing initial dip, resulting from the tendency for fine sediments in caves and microcaves to stick to the walls of the cavity. Bull (1977) showed that fine-grained

Fig. 2: Turbidites in a flooded network cave. A - Sketch of a flooded network cave with a window at point " $X$ " in the cave ceiling. Sediment entering the cave through the window can form a talus cone. The talus cone can slump into the still ponded water, initiating turbidity current; $B$ - Hypothetical distribution of facies deposited by turbidity current propagated from point " $X$ ". sediments in caves could remain stable on slopes in excess of 70 degrees and may adhere to vertical surfaces.

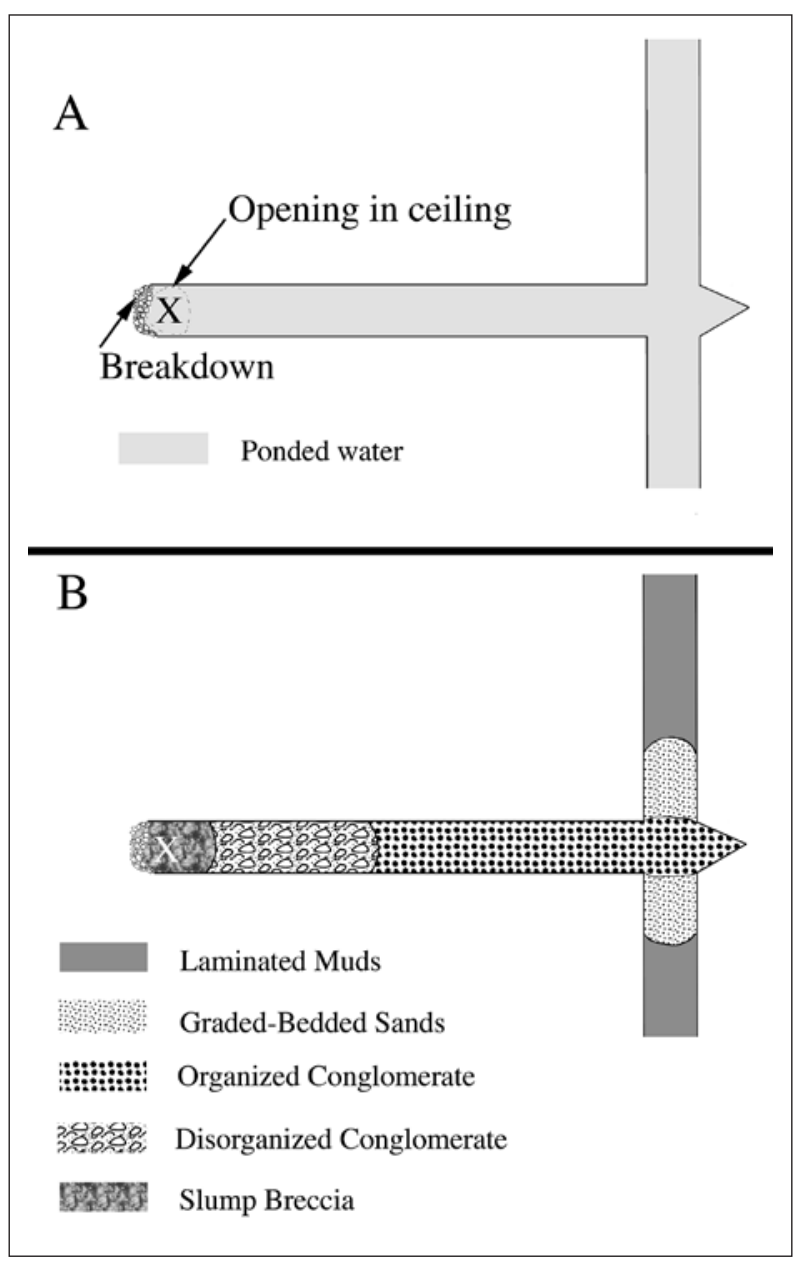


Where the bedrock is horizontally bedded, it is clear that the sloping laminae are a reflection of the initial dip of the turbidite deposit. If the bedrock is dipping and the filled cavity developed along dip then it becomes possible to confuse disconformable palaeokarst with bedrock (see Fig. 1 of Osborne, 2000).

\section{ACTIVE TRUBIDITE DEPOSITION IN CAVES}

Unlike fluvial cave sediments, whose transport and deposition is easily observed in accessible caves, eyewitness accounts of turbidity currents depositing sediment in caves are rare. There are two reasons for this; firstly, most of the palaeokarst microturbidite deposits were deposited in environments too small for human access and secondly cave divers are only just beginning to explore caves where turbidity currents are likely.

\section{REPORT OF AN ACTIVE CAVE TURBIDITY CURRENT}

Hosie \& Smith (2005) reported a potentially fatal cave diving incident that took place in June 2005 in a cave near Kununurra in seasonally wet tropical northern Western Australia. Their account concerns a dive into a cave where visibility had changed overnight from "relatively clear to absolutely atrocious" (Hosie \& Smith, 2005, p. 24). Paul Hosie followed the dive line into the cave, but on his return found the way blocked and the dive line buried under sand. A turbidity current had apparently flowed, blocking a constriction in the cave behind him. Despite almost losing consciousness, Paul Hosie was able to dig his way out and return safely to the surface.

The report is harrowing in detail, but Hosie and Smith's initial conclusion is of great interest: "Turbid flow causing silt slump and cave blockage is a very real risk in Australia's top end caves. Annual wet season deluges will most likely reset these traps" (Hosie \& Smith, 2005, p. 27).

\section{EXAMPLES OF PALAEOKARST AND RELICT TURBIDITE DEPOSITS}

\section{THE WELLINGTON CAVES PHOSPHATE MINE}

The Phosphate Mine at Wellington Caves is a system of mine shafts and drives excavated through an almost completely sediment-filled cave. The mine intersects and exposes a sequence of lithified and partly lithified cave sediments ranging in age from Neogene to Late Pleistocene (Osborne 1982, 1997, 2001). The Pliocene formations, which include the main phosphate deposit, contain a range of facies indicating deposition by turbidity currents. The sequence contains a number of highly unusual rock types, produced from guano piles, rich in bone fragments excreted by carnivorous bats, slumping into still ponds.

\section{Osseous Sandstones (osseous grainstones)}

Osseous sandstones (Osborne, 1982) are clast-supported, graded-bedded sandstones and fine conglomerates in which the sand fraction is almost entirely composed of bone fragments.

Osseous sandstones occasionally occur as thick beds up to $170 \mathrm{~mm}$, but more commonly as sequences of graded layers $50 \mathrm{~mm}$ thick, often terminating in thin mud crack horizons (Fig. 1C). Figures $3 \mathrm{~A}$ and $3 \mathrm{~B}$ show Bouma divisions $\mathrm{A}$ and $\mathrm{B}$ developed in the osseous sand- stones. Coarse blocky spar has strongly recemented these rocks (Fig. 4A and 4B). The initial cement is often phosphate, or acicular carbonate, but later percolating water frequently replaces this with equant spar (Fig. 4C). Sparcemented osseous sandstones are strong rocks, which can resemble quartz arenites to the naked eye, and may be confused with bedrock.

\section{Laminates}

Ripple laminations, Bouma division C, do occur, but are relatively uncommon in the Phosphate Mine turbidites (Fig. 3C). The brown layers in this specimen are composed of clay while the lighter-coloured layers in the ripples are made of phosphatic mudstone with scattered bone fragments. Secondary white apatite fills irregular cavities below the ripples.

\section{Phosphatic mudstone}

The main phosphate deposit at Wellington consists of approximately four metres of poorly-bedded phosphatic mudstone, representing units $\mathrm{D}$ and $\mathrm{E}$ of the Bouma sequence. In thin section, it is seen to consist largely of phosphatic mud with a few scattered grains of vein quartz and small bone fragments (Fig. 4F). 

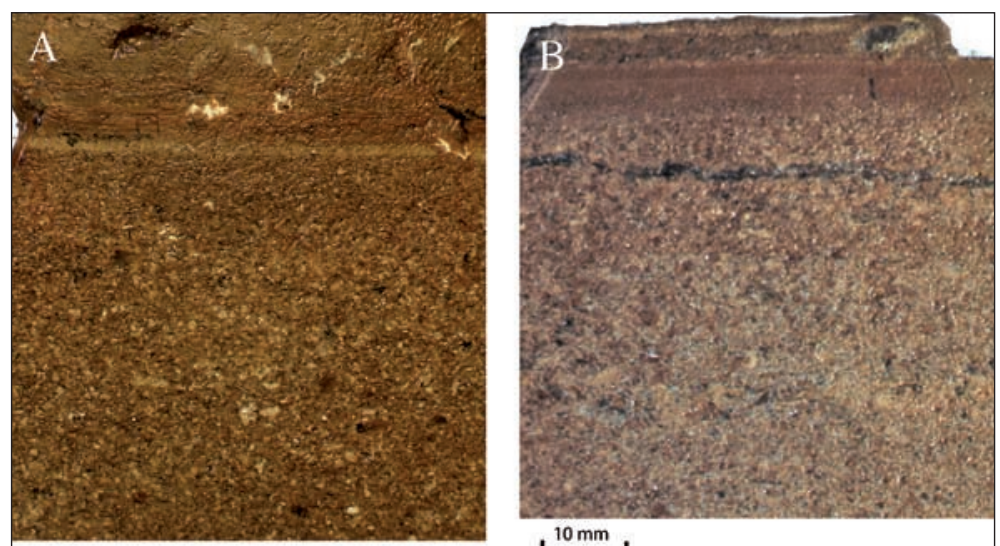

$10 \mathrm{~mm}$
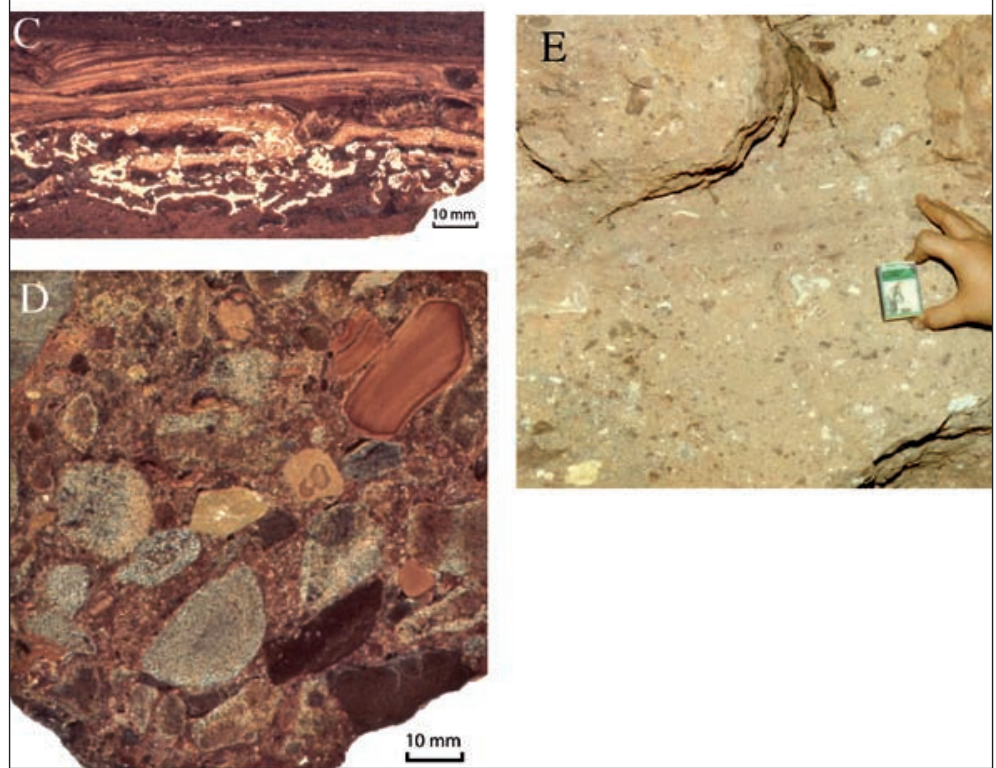

Fig. 3: Turbidite facies from the Wellington Caves Phosphate Mine. A - Lacquered sawn block. Lower part is osseous sandstone and upper part is laminated clay representing Bouma divisions $A$ and $B ; B$ - Lacquered sawn block, consisting of a thick graded bed, a laminated bed, a thin graded bed and at the top a thin laminated clay, representing Bouma divisions $A, B, A, B$; $C$ - Lacquered sawn block showing ripple laminations, representing Bouma division $C$; $D$ - Lacquered sawn block of disorganized conglomerate. Note that the clasts are composed of older cave sediment, not bedrock or surficial deposits; E-Exposure in wall of Phosphate Mine showing organized conglomerate. Note aligned "chocolate chips" (lithified cave sediment lithoclasts) in upper right of image.

\section{COARSE FACIES}

The most important consideration with coarse cave turbidite facies is the origin of the coarse clasts. While surface-derived clasts are the main coarse components of slump and mudflow breccias in caves, these materials are generally too dense for transport by turbidity currents in caves. For this reason, rip up clasts of older lithified cave deposits are the dominant large clasts in coarse cave turbidites. Two types of coarse turbidite facies occur in the Wellington Caves Phosphate Mine sequence. I described these as disorganised conglomerate and organised conglomerate following Walker (1975).

\section{Disorganised Conglomerate}

There is one relatively small deposit of disorganized conglomerate in the Phosphate Mine. It consists of subangular clasts of laminated brown and grey phosphatic mud in a brown matrix (Fig. 3D). These large clasts are all redeposited fragments of older cave sediment. In thin section, the matrix appears as a poorly-sorted mixture of clay pellets, quartz grains (some coated with clay) and phosphatic mud with patches of acicular phosphatic cement (Fig. 4D).

\section{Organised Conglomerate}

The organized conglomerate exposed in the Wellington Caves Phosphate Mine is called "chocolate chip rock", as it consists of aligned clasts of dark brown mudstone set in an off-white matrix (Fig. 3E). In thin section, the matrix appears as osseous sandstone with secondary spar cement (offwhite colour) almost completely replacing the original muddy matrix (Fig. 4E). In addition to the brown mudstone clasts, there are also smaller grey phosphatic mudstone lithoclasts. Some sand-sized quartz grains are present in the osseous sandstone matrix. As with the disorganized conglomerate, all the large clasts in the organized conglomerate are re-worked cave sediments.

\section{FRESHWATER CARBONATE TURBIDITES}

Carbonate muds and sands, can be deposited by turbidity currents in the phreatic zone or as micro-turbidites in perched water bodies in the vadose zone. Fine-grained freshwater turbidites, deposited in holokarsts are frequently difficult to distinguish from marine carbonate mudstones. While they lack obvious fossils so do many marine lime mudstones.

The carbonate sand may be derived from decomposing speleothems, disaggregating coarse marble bedrock or from precipitation in carbonate-saturated water. The fine lime mud may be precipitated in saturated water, the cave equivalent of whiting formed in tropical seas (see Bathurst, 1975, p. 137) or may be a product of incomplete solution as described by Zupan Hajna (2003) 


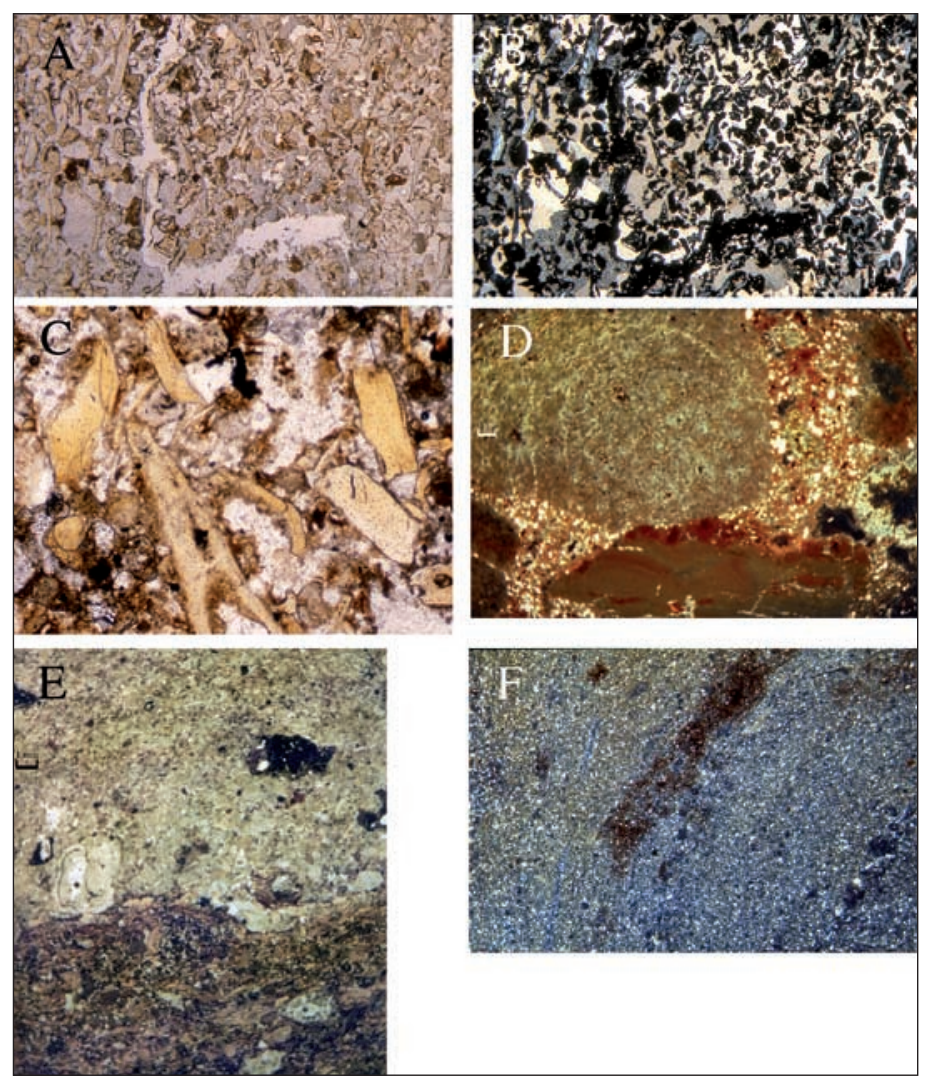

Fig. 4: Wellington Phosphate Mine thin sections. A \& $B$ - Thin sections of osseous sandstone, " $A$ " is under plane-polarized light and " $B$ " is under crossed nicols. In plane-polarised light, the bone fragments are honey coloured, while their low birefringence makes them almost black under crossed nicols. Note spar cement; $C$ - Thin section of osseous sandstone, showing detail of honeyyellow coloured bone fragments. Note brown remnants of original matrix attached to some bone fragments and secondary spar cement; D - Thin section of disorganized conglomerate crossed nicols. Note yellow-grey phosphatic mudstone lithoclasts behind figure number and scale and elongate brown mudstone lithoclast in lower frame; $E$ - Thin section of organized conglomerate in plane-polarized light. Note aligned small grains and dark (brown mudstone) lithoclast in upper half of frame; F - Thin section $10 X$ crossed nicols of phosphatic mudstone from main phosphate deposit. Grey background is phosphatic mud, which is resolved at high power (500x) as radiating crystals. Small light grains are vein quartz clasts.

or result from biogenic weathering (micritization) of the bedrock.

In the absence of convincing field or microfossil evidence, chemical and isotopic analyses may be the only means of distinguishing between lithified freshwater carbonate cave muds and their marine counterparts.

A good example of a freshwater carbonate turbidite comes from an unroofed cave in the surface of the karst plateau adjacent to Trieste, Italy. It consists of finely
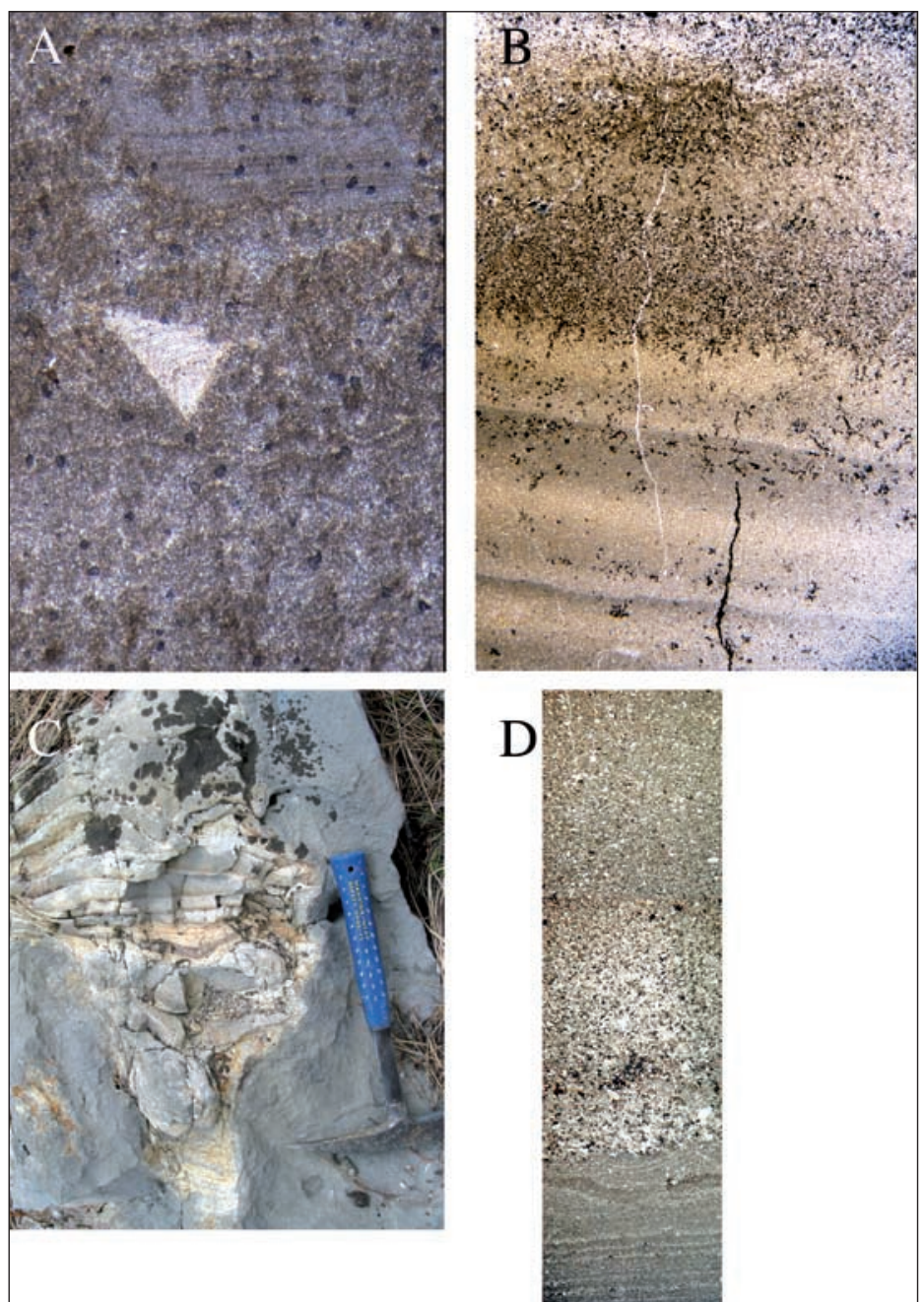

Fig. 5: Freshwater carbonate turbidites and caymanites. A - Thin section of lime mudstone from an unroofed cave in the Trieste Karst, Italy; B - Thin section of graded-bedded carbonate from a filled cave intersected by Črnotiče Quarry southwestern Slovenia. Graded laminae are approximately $4 \mathrm{~mm}$ thick; $C$ - Palaeokarst caymanite microturbidite from Podgrad, Matarsko Podolje, southwestern Slovenia. Bedrock is Upper Cretaceous (Stantonian) limestone; caymanite is probably Late Palaeocene in age. Image is by $B$. Otoničar; $D$ - Thin section, showing details of caymanite illustrated in " $C$ ". Note laminae at base overlain by thick graded bed. Image field of view is approximately $20 \mathrm{~mm}$ long. Image is by B. Otoničar.

laminated lime mudstone recrystallized to microspar, in which a few large idiomorphic calcite crystals have grown (Fig. 5A).

Another example of a probably freshwater gradedbedded carbonate comes from a filled cave intersected by Črnotiče Quarry in southwest Slovenia. In thin section, a series of graded lamina, approximately $4 \mathrm{~mm}$ thick are visible (Fig. 5B). The laminae grade from fine light coloured microspar at the base to brown micrite at the top. 


\section{CAYMANITES: MARINE CARBONATE TURBIDITES}

Marine carbonate sands and muds, deposited in caves flooded by the sea, frequently resemble normal limestones. Jones (1992) described graded-bedded limestones deposited in caves of the Cayman Islands during periods of elevated sea level in the Cainozoic as caymanites. Similar graded-bedded marine palaeokarst sediments of probable Carboniferous age were recognised in eastern Australia by Osborne (1991, 1993). Korpás (1998) and Korpás et al. (1999) described multiple generations of caymanites from the Buda Hills of Hungary. Korpás (2002) listed 32 caymanite deposits internationally, ranging in age from Middle Cambrian to Quaternary.

Caymanites can occur as microturbidite deposits (Figs. 5C and 6C) or more rarely as deposits filling caves large enough for humans to enter (Fig. 6B). It is the outcrop/exposure pattern and stratigraphic relationships of these rocks, not their petrography, which allows them to be recognised as lithified cave deposits.

Korpás (pers. comm.) divides caymanites into conformable and unconformable, the idea being that conformable caymanites are likely to be syndepositional and
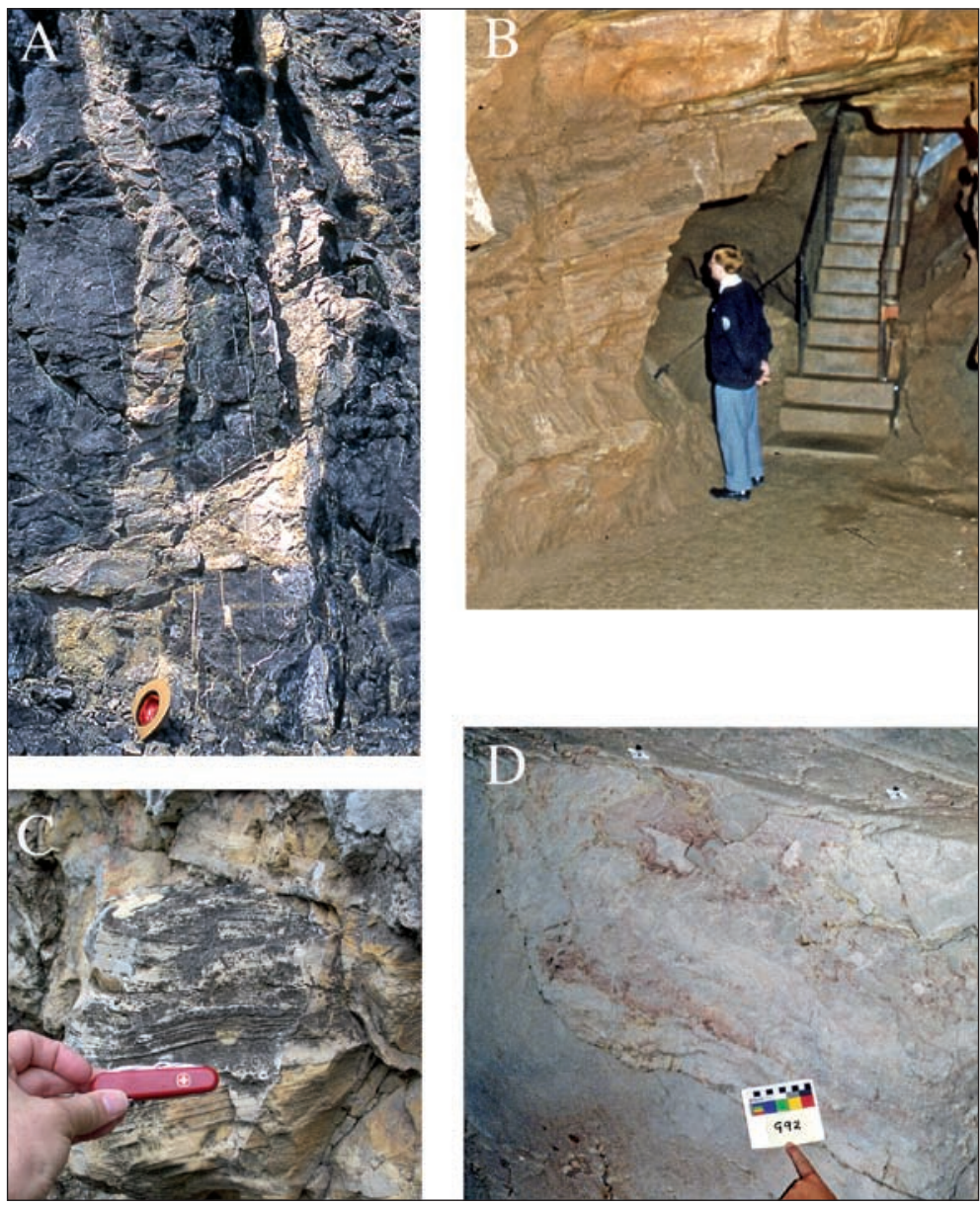

hence the oldest, while unconformable caymanites will be post-tectonic and thus the youngest. While this is a good rule of thumb, it is not always reliable. The caymanites at Ida Bay in Tasmania, Australia, described by Osborne \& Cooper (2001) and shown in Figure 6A are disconformable rather than conformable or unconformable. This tells us little about their age, as the enclosing Ordovician limestone is essentially undeformed. Similarly, the steeply-dipping laminations in Figure 1A are definitely unconformable with the bedrock, but the bedrock here is almost horizontally bedded Cambrian limestone.

While caymanites have similar sedimentology, that is they range in size from mud to gravel and include graded-bedded sands, laminated muds and other units of the Bouma sequence, they vary considerably in composition. This is because coarse grains in caymanites are a sample of the carbonate debris, i.e. the biota with carbonate skeletons present in the ocean when the karst cavities were inundated. This similarity and diversity can be seen in Figures 5, 6 and 7.

The caymanites from Ida Bay shown in Figures $6 \mathrm{~A}$ and $7 \mathrm{~A}$ and from the underground exposure at Jenolan Caves shown in Figures $6 \mathrm{~B}$ and $7 \mathrm{~B}$ are both probably of Early Carboniferous age, yet they are very similar in sedimentology to the Late Palaeocene caymanite from Slovenia shown in Figure 5D. The large clasts in 7A and 7B are fragments of crinoid ossicles seen more clearly in Figure 7C, a thin section of a coarser unit from a related deposit at Colong Caves, NSW.

Fig. 6: Caymanite outcrops. A - Caymanite exposed in wall of Lune River Quarry, Ida Bay, Tasmania, Australia. Caymanite is light-coloured and laminations are visible. Host rock, dark grey is Ordovician Gordon Limestone. The caymanite is probably Early Carboniferous in age. Hat is approximately $320 \mathrm{~mm}$ in diameter; B - Caymanite exposed in wall of River Cave, Jenolan Caves, NSW, Australia. Note bedding with gentle apparent dip to the left. Host rock is Silurian Jenolan Caves Limestone. The caymanite is probably Early Carboniferous in age; C - Caymanite exposed in Fenyőgyöngye Quarry, Budapest, Hungary. Host rock is Upper Eocene Szépvölgy Limestone. The palaeokarst is Late Eocene, see Korpás (1998); D - Caymanite exposed in wall of Cathedral Cave, Wellington Caves, NSW, Australia. Host rock is Devonian Garra Formation. The age of the caymanite is unknown. Black squares on scale $=10 \mathrm{~mm}$. 
These eastern Australian caymanites resemble Carboniferous and Permian cold water limestones that formed

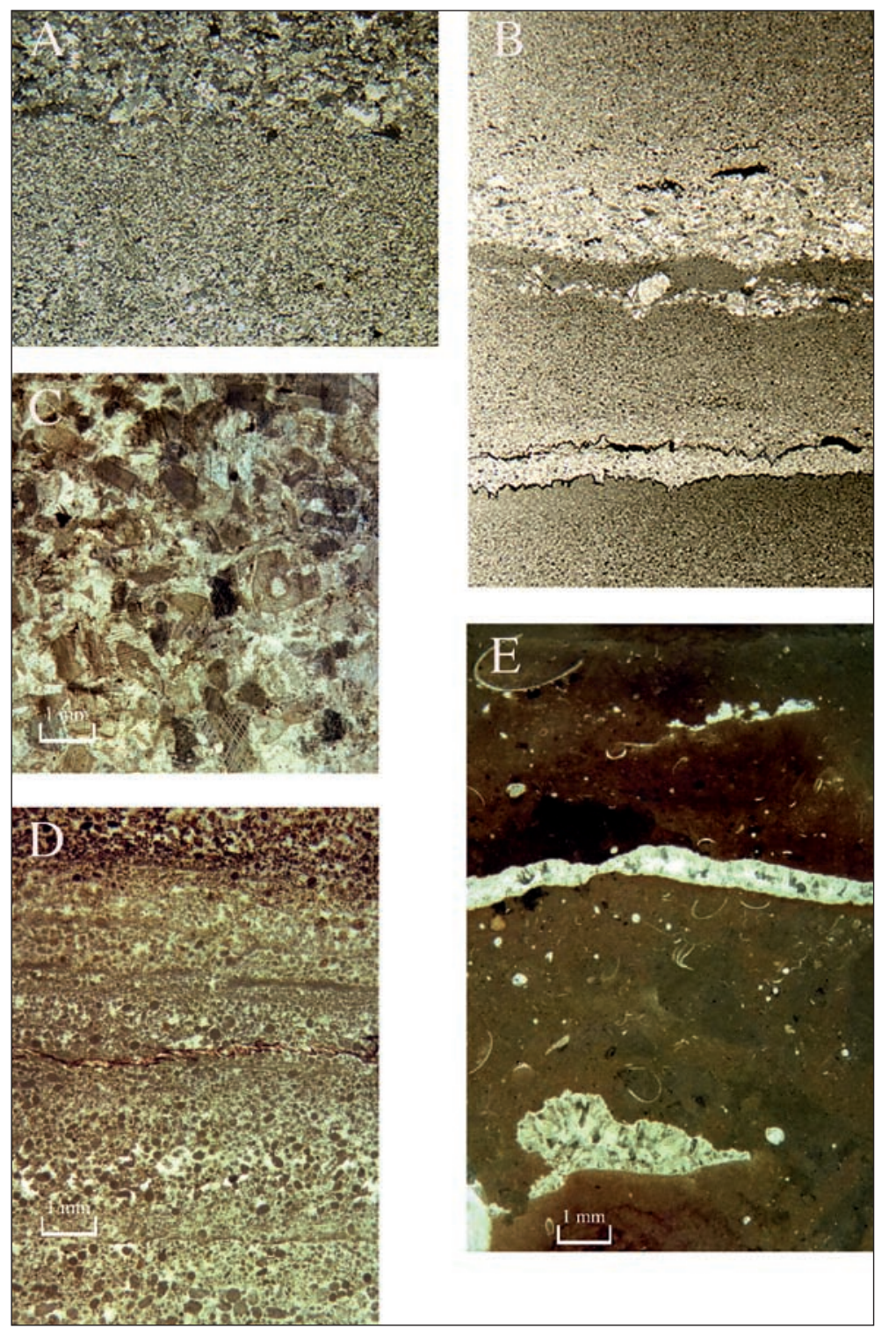

when Australia was part of Gondwana and located at high latitudes. The coarse grains in Figure 5D are foraminifera indicating a quite different marine environment.

Two quite different caymanites are show in Figures 7D and 7E. Figure 7D is a pelletal caymanite with poor grading. It is overlain by the lime mudstone with ostracod fragments shown in Figure 7E. These are unconformable caymanites filing cavities in Silurian limestone at Borenore Caves in central western NSW, Australia. Their age remains undetermined.

At both their original locality in the Cayman Islands (Jones, 1992, 1994) and in Hungary (Korpás 1998; Korpás et al., 1999), caymanites have provided insights into past marine transgressions and sea levels. Caymanites elsewhere have great potential to reveal information about marine transgressions that occurred in the past for which no other evidence is preserved.

Fig. 7: Caymanite thin sections. A - Thin section $3.2 x$ crossed nicols from Lune River Quarry, Ida Bay, Tasmania, Australia, showing top of one graded bed and the base of another;

$B$ - Part of a sequence of graded beds and lime mudstones $3.2 x$ crossed nicols from River Cave, Jenolan Caves, NSW, Australia. Note erosion at base of upper graded bed; $C$ - Coarse crinoidal grainstone $6.4 x$ crossed nicols from exposure in Lannigans Cave, Colong Caves, NSW, Australia; D - Graded-bedded pelletal caymanite $6.4 x$ plane-polarized light from surface outcrop at Borenore Caves, NSW, Australia; E - Lime mudstone with ostracod bioclasts $6.4 x$ crossed nicols from same caymanite sequence as " $D$ ", Borenore Caves, NSW, Australia.

\section{WHERE ARE TRUBIDITES FORMING IN CAVES TODAY AND WHERE SHOULD WE EXPECT TO FIND OLDER ONES?}

There is no problem with finding modern analogues for microturbidite and large-scale caymanites, but modern examples of non-marine turbidite deposition, particularly in human-scale caves remain rare. So where should we look for active cave turbidite deposition and for relict cave turbidites?
Firstly, we should look for turbidites in caves that contain still bodies of water. These could be caves blocked by ice or rockfalls and caves with poor drainage or hydrological connections. Hypogene caves should be good targets. Flooding and extreme rainfall are factors in both Hosie and Smith's example of active turbidite deposition 
and Kos' example of a cave turbidite from South Australia. Flooding and extreme rainfall events are characteristics of both the Australian seasonally wet tropics and of the Australian continent in general with its "droughts and flooding rains" (Mackellar, 1911). On reflection, the Wellington Caves Phosphate Mine turbidites are unsurprising, as they formed in an Australian hypogene cave.

Hypogene caves in seasonally wet tropical regions, or regions with extremely variable rainfall are likely locations for cave turbidites in all continents. In the case of palaeokarst, this will include locations that have had a seasonally wet tropical climate or extremely variable rainfall in the past.

While caymanites usually result from sea level changes, Burney et al. (2001) suggested another mechanism for caymanite deposition, tsunamis. As well as looking for caymanites on carbonate coasts where sea levels were higher in the past, we should also be looking for caymanites along limestone coasts where tsunamis occur. This includes carbonate coasts of the Indonesian archipelago.

\section{ACKNOWLEDGEMENTS}

I would like to thank Bojan Otoničar for long discussions over the years about palaeokarst and petrology both in the field and looking down the microscope and also for the images in Figures 5C and 5D. I am also thankful to László Korpás for his generosity in the field and for helpful discussions and correspondence. Andrej Mihevc assisted with field visits to Črnotiče Quarry and the Trieste Karst. I also wish to record my thanks to Wellington Council and the staff at Wellington Caves for their support for my research for over thirty years. Penney Osborne helped with reading and correcting the drafts.

\section{REFERENCES}

Bathurst, R.G., 1975: Carbonate Sediments and their Diagenesis, Second Enlarged Edition. Developments in Sedimentology, 12, 658 pp., Elsevier, Amsterdam.

Bouma, A.H., 1962: Sedimentology of some Flysch Deposits. Elsevier, 168 pp., Amsterdam.

Bull, P.A., 1977: Laminations or varves? Processes and mechanisms of fine grain sediment deposition in caves. Proceedings of the 7th International Speleological Congress, Sheffield, 86-89.

Burney, D.A., James, H.F., Burney, L.P., Olson, S.L., Kikuchi, W., Wagner, W. 1., Burney, M., McCloskey, D., Kikuchi, D., Grady, F.V., Gage, R. II \& Nishek, R., 2001: Fossil evidence for a diverse biota from Kaua’i and its transformation since human arrival. Ecological Monographs, 71/4, 615-641.

Grover, N.C. \& Howard, C.S., 1938: The passage of turbid water through Lake Mead. Transactions of the American Civil Engineering Society, 103, 720-790.

Hosie, P. \& Smith, K., 2005: Cave Diving Death Trap. Caves Australia, 166-167, 24-27.

Jones, B., 1992: Caymanite, a cavity-filling deposit in the Oligocene-Miocene Bluff Formation of the Cayman Islands. Canadian Journal of Earth Science, 29, 720735
Jones, B., 1994: Void-filling deposits in karst terrains of isolated oceanic islands: a case study from Tertiary carbonates of the Cayman Islands. Sedimentology, $39,857-876$

Korpás, L., 1998: Palaeokarst Studies in Hungary. Occasional Paper, 195, 139 p., Geological Institute of Hungary, Budapest.

Korpás, L., Lantos, M \& Nagymarosy, A., 1999: Timing and genesis of early marine caymanites in the hydrothermal palaeokarst system of Buda Hills, Hungary. Sedimentary Geology, 123, 9-29

Korpás, L., 2002: Are palaeokarst systems marine in origin? Caymanites in geological past. In: F. Gabrovsek (Ed.): Evolution of Karst from Prekarst to Cessation. Zalozba ZRC, Postojna-Ljubljana, 415-424

Kos, A.M., 2001: Stratigraphy, sedimentary development and palaeoenvironmental context of a naturally accumulated pitfall cave deposit from southeastern Australia. Australian Journal of Earth Sciences, 48/5, 621-632.

Mackellar, D., 1911: My Country, The Closed Door. Australasian Authors' Agency, 9-11, Melbourne. 
Marschalko, R. \& Mello, J., 1993: Turbidites as fillings of cavities in Triassic limestones of the Silica Nappe (Western Carpathians, Plešivec Karst Plateau). Geologica Carpathica, 44/1, 35-42

Otoničar, B., 1997: Macroscopic paleokarstic features in Upper Cretaceous limestones of the Adriatic-Dinaric carbonate platform (SW Slovenia). Proceedings. 12th International Congress of Speleology, Speleo Projects, La Chaux-de-Fonds, Switzerland, 417-420.

Osborne, R.A.L., 1982: Cainozoic stratigraphy at Wellington Caves, New South Wales. Proceedings of the Linnean Society of New South Wales, 107/2, 131147

Osborne, R.A.L., 1991: Palaeokarst deposits at Jenolan Caves, NSW. Journal and Proceedings of the Royal Society of New South Wales, 123/3-4, 59-73.

Osborne, R.A.L., 1993: Geological Note: Cave formation by exhumation of Palaeozoic palaeokarst deposits at Jenolan Caves, New South Wales. Australian Journal of Earth Sciences, 40, 591-593.

Osborne, R.A.L., 1997: Rehabilitation of the Wellington Caves Phosphate Mine: implications for Cainozoic stratigraphy. Proceedings of the Linnean Society of New South Wales, 117, 175-180.

Osborne, R.A.L, 2000: Paleokarst and its Significance for Speleogenesis. In: A.B. Klimchouk, D.C. Ford, A.N. Palmer \&W. Dreybrodt (Eds.): Speleogenesis, Evolution of Karst Aquifers. Huntsville, National Speleological Society, p. 113-123.
Osborne, R.A.L., 2001: Karst geology of Wellington Caves, a review. Helictite, 37/1, 3-12.

Osborne, R.A.L., 2007: Intensely lithified palaeokarst deposits in Okno Cave, Demänovská Valley (Slovakia). Geologica Carpathica, 58/6, 565-578.

Osborne, R.A.L. \& Cooper, I.B., 2001: Sulfide-bearing palaeokarst deposits at Lune River Quarry, Ida Bay, Tasmania. Australian Journal of Earth Sciences, 48, 409-416.

Valen, V., Larsen, E. \& Mangerud, J., 1995: High resolution paleomagnetic correlation of Middle Weichselian ice-dammed lake sediments in two coastal caves, western Norway. Boreas, 42, 141-153.

Walker, R.G., 1969: The juxtaposition of turbidite and shallow-water sediments: study of a regressive sequence in the Pennsylvanian of north Devon, England. Journal of Geology, 77, 125-143

Walker, R.G., 1975: Generalised facies models for resedimented conglomerates of turbidite association. Bulletin of the Geological Society of America, 86, 737 748 .

Zupan Hajna, N., 2003: Incomplete Solution: Weathering of cave walls and the production, transport and deposition of carbonate fines. Zalozba ZRC, 167 pp., Ljubljana. 